\title{
Cerebrospinal fluid adenosine 3',5'-monophosphate, 5-hydroxyindoleacetic acid and homovanillic acid in patients with sleep apnoea syndrome
}

\author{
H CRAMER, $*$ J-M WARTER, $\dagger$ B RENAUD, $\ddagger$ J KRIEGER, $\dagger$ CHR MARESCAUX, $\dagger$ \\ R HAMMERS*
}

From the Department of Neurology, University of Freiburg, ${ }^{*}$ the Department of Neurology, University of Strasbourg, $\dagger$ the Department of Neurology, University of Lyon $\ddagger$

SUMmARY Adenosine 3',5'-monophosphate (cyclic AMP), 5-hydroxyindoleacetic acid (5-HIAA) and homovanillic acid (HVA) were determined in the cerebrospinal fluid of patients with respiratory disorder and hypersomnia and in control patients. Patients with the sleep apnoea syndrome confirmed polygraphically showed elevated levels of cyclic AMP and 5-HIAA. Cyclic AMP levels were inversely correlated with arterial $\mathrm{PO}_{2}$, measured under resting conditions. The level of $\mathrm{HVA}$ also was raised, but the change was not statistically significant.

Catecholamine and indoleamine neurotransmitters play a key role in the central regulation of sleep and vigilance. While serotonergic pathways have been implicated in the appearance mainly of slow wave sleep, other evidence suggests an association of dopamine metabolism with REM-sleep. ${ }^{1}$ Hypersomnia with periodic sleep apnoea (Pickwicksyndrome, sleep apnoea syndrome) is a disorder of unknown aetiology, characterised by episodes of respiratory arrest during sleep and obstructive or central hypercapnia associated with day-time somnolence in obese subjects. ${ }^{2-4}$ Recently, elevated levels of the serotonin metabolite 5-hydroxyindoleacetic acid (5-HIAA) ${ }^{5}$ and the dopamine metabolite homovanillic acid (HVA) ${ }^{6}$ in the cerebrospinal fluid (CSF) have been reported in this condition. It has been suggested that such metabolic changes might be caused by the obstructive apnoea and might be linked to the day-time sleepiness, which then could be viewed as a secondary disturbance. ${ }^{6}$

Other evidence indicates that the neurotransmitters serotonin and dopamine control the synthesis of adenosine $3^{\prime}, 5^{\prime}$-monophosphate (cyclic AMP) in the brain, ${ }^{78}$ and cerebral glucogenolysis in response

Address for reprint requests: Prof H Cramer, Department of Neurology, Hansastr 9, D-7800 Freiburg, West Germany.

Received 21 June 1981

Accepted 27 August 1981 to these hormones and to anoxia appears to be mediated by this cyclic nucleotide. ${ }^{910}$ Indirect evidence for an involvement of cyclic AMP in the regulation of sleep in the brain stem has been reviewed elsewhere. ${ }^{11}$ In this paper we report the results of a study of cerebrospinal fluid levels of cyclic AMP and of the monoamine metabolites HVA and 5-HIAA in patients with the sleep apnoea syndrome and respiratory disorders.

\section{Patients and methods}

Eight patients (seven males, one female, mean age 53.6 years) were studied for suspicion of the sleep apnoea syndrome. All presented with obesity and complaints of diurnal somnolence (table 1). The patients were subjected to complete tests of cardiorespiratory functions including blood gas analysis in the resting condition, all-night polygraphic recording of EEG, EMG, eye movements and respiration, and lumbar puncture with analysis of CSF, in addition to thorough neurological examination, radiography of the skull and routine laboratory examinations.

Seven patients (five males, two females, mean age 39.4 $\pm 5 \cdot 2$ years) who consulted for lumbago and suspicion of vertebral disc herniation served as controls. All patients were free of central nervous system disease. Routine CSF values (protein content, cell count) were normal. Lumbar punctures were performed in the decubitus position. Eight $\mathrm{ml}$ of CSF were removed, aliquots were immediately frozen and stored at $-40^{\circ} \mathrm{C}$ until analysis. Cyclic 
Table 1 Clinical data and results of blood cell count and gas analysis in patients with respiratory disturbances and hypersomnia

\begin{tabular}{|c|c|c|c|c|c|c|c|c|c|c|c|}
\hline \multirow{2}{*}{$\begin{array}{l}\text { Patient } \\
\text { age }(y r) \\
\text { sex }\end{array}$} & \multirow[t]{2}{*}{ Diagnosis } & \multirow{2}{*}{$\begin{array}{l}\text { Diurnal } \\
\text { somnolence }\end{array}$} & \multirow{2}{*}{$\begin{array}{l}\text { Polygraphic } \\
\text { recording }\end{array}$} & \multirow{2}{*}{$\begin{array}{l}\text { Other } \\
\text { symptoms }\end{array}$} & \multirow{2}{*}{$\begin{array}{l}\text { Body } \\
\text { weight } \\
(k g)\end{array}$} & \multirow{2}{*}{$\begin{array}{l}\text { Erythrocyte } \\
\text { count } \\
\text { (million } / \mathrm{mm}^{2} \text { ) }\end{array}$} & \multirow{2}{*}{$\begin{array}{l}\text { Arterial } \\
p H\end{array}$} & \multicolumn{3}{|c|}{ Art blood gas analysis } & \multirow{2}{*}{$\begin{array}{l}\text { Drug } \\
\text { treatm }\end{array}$} \\
\hline & & & & & & & & $\mathrm{PO}_{2}$ & $\mathrm{PCO}_{2}$ & $\begin{array}{l}\text { Oxygen } \\
\text { saturation } \\
(\%)\end{array}$ & \\
\hline RE $51 \mathrm{M}$ & $\begin{array}{l}\text { sleep apnoea } \\
\text { syndrome }\end{array}$ & + & $\begin{array}{l}\text { frequent } \\
\text { episodes of } \\
\text { sleep apnoea }\end{array}$ & $\begin{array}{l}\text { chronic } \\
\text { bronchitis }\end{array}$ & 102 & $4 \cdot 3$ & $7 \cdot 43$ & 47 & 57 & $85 \%$ & none \\
\hline RO 45 M & $\begin{array}{l}\text { sleep apnoea } \\
\text { syndrome }\end{array}$ & + & $\begin{array}{l}\text { episodes of } \\
\text { sleep apnoea }\end{array}$ & $\begin{array}{l}\text { chronic } \\
\text { bronchitis }\end{array}$ & 113 & $6 \cdot 0$ & $7 \cdot 45$ & $38 \cdot 5$ & $49 \cdot 5$ & $75 \%$ & none \\
\hline RS $52 \mathrm{M}$ & $\begin{array}{l}\text { sleep apnoea } \\
\text { syndrome }\end{array}$ & + & $\begin{array}{l}\text { episodes of } \\
\text { sleep apnoea }\end{array}$ & none & 91 & $4 \cdot 5$ & $7 \cdot 41$ & 65 & 35 & $93 \%$ & none \\
\hline BR $70 \mathrm{M}$ & $\begin{array}{l}\text { sleep apnoea } \\
\text { syndrome }\end{array}$ & + & $\begin{array}{l}\text { episodes of } \\
\text { sleep apnoea }\end{array}$ & none & 100 & $4 \cdot 4$ & $7 \cdot 45$ & 55 & $39 \cdot 5$ & $90 \%$ & none \\
\hline GI 59 M & $\begin{array}{l}\text { sleep apnoea } \\
\text { syndrome }\end{array}$ & + & $\begin{array}{l}\text { episodes of } \\
\text { sleep apnoea }\end{array}$ & $\begin{array}{l}\text { light } \\
\text { diabetes }\end{array}$ & 101 & $4 \cdot 4$ & $7 \cdot 39$ & 70 & $35 \cdot 5$ & $90 \%$ & $\begin{array}{l}\text { oral } \\
\text { antidi }\end{array}$ \\
\hline GA 44 M & $\begin{array}{l}\text { chronic } \\
\text { respiratory } \\
\text { insufficiency }\end{array}$ & + & normal & none & 79 & $5 \cdot 8$ & $7 \cdot 39$ & 55 & 39 & $90 \%$ & none \\
\hline LA $46 \mathrm{M}$ & $\begin{array}{l}\text { chronic } \\
\text { bronchitis }\end{array}$ & + & normal & none & 107 & $4 \cdot 8$ & $7 \cdot 39$ & $51 \cdot 5$ & $38 \cdot 2$ & $90 \%$ & none \\
\hline FA 62 F & $\begin{array}{l}\text { chronic } \\
\text { bronchitis }\end{array}$ & + & normal & none & 100 & $4 \cdot 2$ & $7 \cdot 54$ & 56 & 28 & $90 \%$ & none \\
\hline
\end{tabular}

AMP was determined by radioimmunoassay with equilibrium analysis according to Cailla et al (1973) in triplicate samples. HVA was determined fluorimetrically according to Renaud et al. ${ }^{12}$ 5-HIAA was measured by the method of Korf and Valckenburgh-Sikkema. ${ }^{13}$ For statistical analysis the test of Cochrane and Student's $t$ test were applied.

\section{Results}

Of the eight patients with diurnal somnolence and obesity five were diagnosed as having the sleep apnoea syndrome (table 1). The other three patients had normal polygraphic recordings with no apnoeic episodes. Polycythaemia was present in two patients, one with the sleep apnoea syndrome and one with chronic respiratory insufficiency. All patients had some degree of hypoxia as evidenced by a decrease of Po . Hypercapnia not corrected by hyperventilation existed only in the first two patients with sleep apnoea syndrome (table 1). Oxygen saturation was least in these patients.

As shown in table 2 the mean level of cyclic AMPO was markedly alevated $(p<0.005)$ in the group of patients with the sleep apnoea syndrome in com $\frac{0}{10}$ 을 parison to int control group of patients. The levels of HVA showid targe variations and the mean levek was not statistically significantly increased in sleepô apnoea patients. The levels of 5-HIAA were in creased $(\mathrm{p}<0001)$ in sleep apnoea patients aso compared to other obese patients with respiratory. disease and diurnal somnolence, as well as with the control group of patients free of central nervous

Table 2 Cerebrospinal fluid cyclic AMP, HVA and 5-HIAA in patients with sleep apnoea syndrome, respiratory disease with diurnal somnolence and in control patients

\begin{tabular}{|c|c|c|c|}
\hline Patients & Cyclic AMP (pmol/ml) & Homovanillic acid $(\mathrm{ng} / \mathrm{ml})$ & 5-hydroxyindoleasetic acid $(\mathrm{ng} / \mathrm{ml})$ \\
\hline \multicolumn{4}{|c|}{ Sleep apnoea syndrome } \\
\hline RE & 42 & 21 & 56 \\
\hline RO & 45 & 80 & 74 \\
\hline RS & 29 & 9 & 34 \\
\hline BR & 20 & 136 & 63 \\
\hline \multirow[t]{2}{*}{ GI } & 14 & 63 & 44 \\
\hline & total: $30 \cdot 0 \pm 6 \cdot 0^{*}$ & $61 \cdot 8 \pm 22 \cdot 7$ & $54 \cdot 2 \pm 7 \cdot 0 \dagger$ \\
\hline \multicolumn{4}{|c|}{ Respiratory disease } \\
\hline GA & 33 & 11 & 21 \\
\hline LA & 6 & 6 & 22 \\
\hline $\mathbf{F A}$ & 20 & 39 & 17 \\
\hline & total: $19 \cdot 7 \pm 7 \cdot 8$ & $18 \cdot 7 \pm 10 \cdot 2$ & $20 \cdot 0 \pm 1 \cdot 5$ \\
\hline \multicolumn{4}{|c|}{ Control patients } \\
\hline & total: $15 \cdot 5 \pm 2 \cdot 9$ & $29 \cdot 8 \pm 7 \cdot 5$ & $20 \cdot 7 \pm 2 \cdot 2$ \\
\hline
\end{tabular}

$* \mathrm{p}<0.005$ vs control patient group.

$\dagger \mathrm{p}<0.001$ vs control patient group. 
system disease. Within the group of sleep apnoea patients there was a correlation between the levels of cyclic AMP and $\mathrm{Po}_{2}(\mathrm{r}=-0.86, \mathrm{p}<0.05)$. Further, a correlation was found between 5-HIAA and $\mathrm{Po}_{2}(\mathrm{r}=-0.86, \mathrm{p}<0.05)$. No correlation was apparent between HVA and the values of blood gas analysis.

\section{Discussion}

Cyclic AMP levels in CSF are elevated in patients with sleep apnoea syndrome. Moreover, the cyclic AMP levels are positively correlated to the degree of hypoxia and of hypercapnia in our patients. This finding is not specific for the sleep apnoea syndrome, but is a reflection of the metabolic disturbance induced by hypoxia, for we also found an increased level of cyclic AMP in a patient with polycythaemia, as a result of chronic hypoxia due to primary respiratory disease. Increased cyclic AMP levels in the CSF appear to be a useful indicator of central hypoxia, as has been shown also in animal experiments. ${ }^{14}$ Evidence for locally increased cyclic AMP metabolism was also reported in patients with cerebral infarction. ${ }^{15}$

The observation of increased levels of 5-HIAA in the sleep apnoea syndrome confirms earlier preliminary reports. ${ }^{5}{ }^{6}$ Normal levels of 5-HIAA were found in the small group of patients with respiratory disease and diurnal somnolence but undisturbed sleep. In contrast to Baruzzi's observation ${ }^{6}$ in only two cases, our patients showed a statistically insignificant elevated mean level of HVA; marked increases in some patients were not correlated with any of the other metabolic parameters tested.

Our findings suggest that serotonergic systems and cyclic AMP as a second messenger are involved in the sleep apnoea syndrome. Apparently, neither the serotonin metabolite nor cyclic AMP is altered in other syndromes with hypersomnia such as narcolepsy and the subwakefulness syndrome (Cramer et $a l$, unpublished observation). While cyclic AMP levels may reflect cerebral hypoxia, the disturbance of serotonin metabolism may be more specifically connected to the sleep disorder in the sleep apnoea syndrome. Under severe cerebral ischaemia, brain levels of serotonin were decreased. ${ }^{16}$ This would be in accordance with the role of serotonin in sleep suggested by Jouvet. ${ }^{17}$ Baruzzi et al ${ }^{6}$ have shown that 5-HIAA and HVA levels in the CSF decreased in one patient after tracheostomy, concomitant with the clinical disappearance of the sleep disorder. It would be interesting to correlate cyclic nucleotide levels with the course of the disease in individual patients with sleep apnoea, in order to clarify their role in the disease process.

\section{References}

${ }^{1}$ Renaud B, Quincy C, Mouret J, Jouvet M. La durée du sommeil paradoxal chez l'homme. Relations éventuelles avec le métabolism de la dopamine. Nouv Press Méd 1975;4:1656.

${ }^{2}$ Gastaut H, Tassinari CA, Duron B. Etude polygraphique des manifestations épisodiques (hypniques et respiratoires) du Syndrome de Pickwick. Rev Neurol (Paris) 1965;112:568-79.

${ }^{3}$ Kuhlo W. Neurophysiologische und klinische Untersuchungen beim Pickwick-Syndrom. Arch Psychiatr Nervenkr 1968;211:170-92.

${ }^{4}$ Lugaresi E, Coccagna G, Mantovani M. Hypersomnia with periodic apneas. Spectrum, New York. 1978.

5 Mangin P, Krieger J, Borg J, Warter JM, Kurtz D. Biogenic amine metabolism in sleep apnea syndrome. Adv Biosci 1979;21:217-9.

${ }^{6}$ Baruzzi A, Cirignotta F, Coccagna G, Calderini G, Lugaresi E. Cerebrospinal fluid homovanillic acid and 5-hydroxyindoleacetic acid in hypersomnia with periodic apneas or idiopathic hypersomnia: preliminary results. Sleep 1980;3:247-9.

' Pagel J, Christian ST, Quayle ES, Monti JA. A serotonin sensitive adenylate cyclase in mature rat brain synaptic membranes. Life Sci 1976;19:819-24.

${ }^{8}$ Kebabian JW, Petzold GL, Greengard P. Dopaminesensitive adenylate cyclase in caudate nucleus of rat brain and its similarity to the "dopamine receptor". Proc Natl Acad Sci (USA) 1972;69:2145-9.

${ }^{9}$ Mrsulja BB. Cyclic nucleotides and brain glycogen. Experientia 1974;30:66-7.

${ }^{10}$ Lust WD, Goldberg ND, Passonneau JV. Cyclic nucleotides in murine brain: The temporal relationship of changes induced in adenosine $3^{\prime}, 5^{\prime}$-monophosphate during maximal electroshock or decapitation. $J$ Neurochem 1976;26:5-10.

${ }^{11}$ Cramer H, Clarenbach P. Nucléotides cycliques, vigilance et sommeil. In : Passouant $P$, Oswald I, eds. Pharmacology of the states of alertness. Oxford, New York: Pergamon Press, 1979:15-27.

${ }^{12}$ Renaud B, Quenin P, Quincy C. Détermination fluorimétrique en flux continu de l'acide homovanillique. Application au liquide céphalorachidien. Clin Chim Acta 1974;52:179-85.

${ }^{13}$ Korf J, Valkenburgh-Sikkema T. Fluorimetric determination of 5-hydroxy-indoleacetic acid in human urine and cerebrospinal fluid. Clin Chim Acta 1969; 26:301-6.

${ }^{14}$ Cramer H, Hammers R, Clarenbach P, Horstmann R. Occurrence and significance of cyclic nucleotides in the cerebrospinal fluid. Internat J Neurol 1979;13: 25-35.

${ }^{15}$ Welch KMA, Meyer JS, Chee ANC. Evidence for disordered cyclic AMP metabolism in patients with cerebral infarction. Eur Neurol 1975;13:144-54.

${ }^{16}$ Harrison MJG, Marsden CD, Jenner P. Effect of experimental ischaemia and neurotransmitter amines in the gerbil brain. Stroke 1979;10:165-8.

17 Jouvet M. The role of monoamine and acetylcholine containing neurons in the regulation of the sleepwaking cycle. Ergebn Physiol 1972;64:166-307. 